\title{
Expression of Heat Shock Proteins in Brain Tumors
}

\author{
Beyin Tümörlerinde Isı Şok Proteinlerinin Ekspresyonu
}

George A ALEXIOU ${ }^{1}$, Achilleas KARAMOUTSIOS ${ }^{2}$, George LALLAS ${ }^{3}$, Vasilios RAGOS ${ }^{1}$, Ann GOUSSIA ${ }^{4}$, Athanasios P KYRITSIS 5 , Spyridon VOULGARIS ${ }^{1}$, George VARTHOLOMATOS ${ }^{2}$

${ }^{1}$ University Hospital of Ioannina, Department of Neurosurgery, Ioannina, Greece

2University Hospital of Ioannina, Hematology Laboratory, Ioannina, Greece

${ }^{3}$ Flowcytogen Laboratories Ltd Koropi, Athens, Greece

${ }^{4}$ University Hospital of Ioannina, Department of Pathology, Ioannina, Greece

${ }^{5}$ University Hospital of Ioannina, Department of Neurology, Ioannina, Greece

Corresponding Author: George A ALEXIOU / E-mail: alexiougrg@yahoo.gr, alexiougr@gmail.com

\begin{abstract}
AIM: Heat shock proteins (HSP) are an evolutionary conserved family of proteins that serve as molecular chaperones, preventing the formation of nonspecific protein aggregates and assisting proteins in the acquisition of their native structures. Furthermore, HSPs have anti-apoptotic properties and have been found to be elevated in many human cancers; their overexpression has been associated with poor survival and response to therapy. In the present study we assessed the HSP expression in brain tumors.
\end{abstract}

MATERIAL and METHODS: Simultaneous detection of HSP27, HSP40, HSP60, HSP70, HSP90a, total Akt and phospho- Akt in 19 brain tumor specimens was performed using the multiplex bead array assay.

RESULTS: There was expression of HSP27 (pSer ${ }^{82}$ ), HSP27 (pSer ${ }^{15}$ ), HSP40, HSP60, HSP70, HSP90a, total-Akt and phospho- Akt in both gliomas and meningiomas. Significantly higher levels of HSP70 and a trend towards higher levels of HSP40 were found in meningiomas compared to gliomas. There was a significant correlation between HSP27 $\left(\mathrm{pSer}^{82}\right)$ and HSP27 $\left(\mathrm{pSer}^{15}\right)$ expression and between HSP90a and both total-AKT and phospho- AKT. A significant correlation between HSP27 and total-AKT was observed.

CONCLUSION: Since HSPss are an attractive target for anticancer therapy, further studies are needed in order to better assess their relationship with tumor aggressiveness and patient prognosis.

KEYWORDS: Heat shock proteins, Brain tumor, Glioma, Meningioma

öz

AMAÇ: Isı şok proteinleri (HSP) moleküler bakıcılar görevi görüp non-spesifik protein agregatlarının oluşmasını önleyen ve proteinlere doğal yapılarının kazanıımasında yardımcı olan, evrimsel olarak korunmuş bir protein ailesidir. Ayrıca, HSP'lerin anti-apoptotik özellikleri vardır ve birçok insan kanserinde arttıkları bulunmuştur; aşırı ekspresyonları zayıf sağkalım ve tedavi cevabıyla ilişkilendirilmiştir. Mevcut çalışmada, beyin tümörlerinde HSP ifadesini değerlendirdik.

YÖNTEM ve GEREÇLER: Multipleks boncuk dizisi testini kullanarak 19 beyin tümörü numunesinde HSP27, HSP40, HSP60, HSP70, HSP90a, total Akt ve fosfo- Akt'yi eş zamanlı olarak saptadık.

BULGULAR: Hem gliomalar hem de menenjiyomlarda HSP27 (pSer ${ }^{82}$ ), HSP27 (pSer ${ }^{15}$ ), HSP40, HSP60, HSP70, HSP90a, total-Akt ve fosfoAkt ifadesi yoktu. Menenjiyomlarda gliomalara göre önemli ölçüde daha yüksek HSP70 seviyeleri ve daha yüksek HSP40 seviyeleri eğilimi bulunmaktaydı. HSP27 (pSer ${ }^{82}$ ) ve HSP27 (pSer ${ }^{15}$ ) ifadesi ile HSP90a ve hem total-AKT hem fosfo-AKT arasında önemli bir korelasyon vardı. HSP27 ile total-AKT arasında önemli bir korelasyon gözlendi.

SONUÇ: HSP, antikanser tedavi için çekici bir hedef olduğundan tümör agresifliği ve hasta prognozuyla ilişkisini daha iyi değerlendirmek için ek çalışmalar gerektirir.

ANAHTAR SÖZCÜKLER: Isı şok proteinleri, Beyin tümörü, Glioma, Menenjiyom

\section{INTRODUCTION}

Heat shock proteins (HSP) are evolutionary conserved family of proteins that serve as molecular chaperones, preventing the formation of nonspecific protein aggregates and assisting proteins in the acquisition of their native structures $(2,5,6$, 21). Furthermore, HSPs have anti-apoptotic properties and have been found elevated in many human cancers; their overexpression has been associated with poor survival and response to therapy $(5,6,14)$. HSPs have therapeutic implications since they can be targeted by drugs or may provide a possible target for immunotherapy $(5,20)$. Regarding brain tumors, HSP expression in selected cell lines under heat shock or normal environments has been studied (13). Using mainly immunohistochemistry, high HSP expression has been found in brain tumors $(2,3,13)$. Nevertheless, the majority of studies have only investigated selected HSP. Herewith, we report on the simultaneous detection of HSP27, HSP40, HSP60, HSP70, HSP90a, total Akt and phospho Akt in 19 brain tumor specimens by using multiplex bead array assay. This 
is the first study in which such a large number of HSPs have been investigated in human brain tumors.

\section{MATERIAL and METHODS}

We studied 19 patients (10 males, 9 females, mean age 55.3, range 34-78) with brain tumors that were treated surgically in our institute. Nine patients suffered from glioblastoma, 1 from anaplastic oligoastrocytoma, 6 from typical meningiomas, 1 from atypical meningioma, 1 from acoustic neuroma and 1 from a metastatic brain tumor. We used tissue from surgically excised brain tumor specimens. All patients gave their informed consent to participate in the study.

\section{Sample Preparation}

We used frozen tissues from brain tumor specimens. For the tissue extracts, we followed the protocol suggested in the kit insert. In brief, we placed $\sim 0.5 \mathrm{~cm}^{3}$ piece of tissue in a mortar and added a sufficient volume of liquid nitrogen to cover the tissue, allowing the liquid nitrogen to evaporate (the tissue should be thoroughly frozen). Then we grinded the frozen tissue to a powder with a pestle and added $1 \mathrm{ml}$ of HSP/ Chaperone Lysis Buffer supplement with protease inhibitor cocktail (Sigma, Catalog \# P8340) at a concentration of $0.5 \mu \mathrm{L} /$ $\mathrm{mL}$, phosphatase inhibitor cocktail (Sigma, Catalog \# P2850) at a concentration of $10 \mu \mathrm{L} / \mathrm{mL}$, and PMSF (Sigma Catalog \# P7626) at a concentration of $10 \mu \mathrm{L} / \mathrm{mL}$. We then continued to homogenize the tissue with the pestle until the tissue suspension became homogeneous and passed through a syringe $21 \mathrm{~g} 5$ times in order to ensure full lysis of the cells. The extracts were transferred to a polypropylene tube vortex and incubated on ice for $30 \mathrm{~min}$. Then, they were centrifuged at $16,000 \times \mathrm{g}$ for 20 minutes in a $4^{\circ} \mathrm{C}$ refrigerated microfuge. The supernatant was transferred to a labeled polypropylene tube. The supernatant collected was the tissue extract, ready for analysis. The resulting pellet was discarded. Alternatively, the tissue extracts can be frozen at $-70^{\circ} \mathrm{C}$ and assayed at a later date.

\section{Multibead Analysis Procedure}

We quantified 8 different molecules (Total Akt, Akt phospho - ser473, HSP60, HSP70, HSP90a, HSP40, HSP27 phospho - ser82, HSP27 phospho - ser15) per sample following the suggested procedure of Multibead HSP/Chaperons 8-plex kit (Catalog \# ADI - 980-002, Enzolifescienses). In brief, we used $50 \mu \mathrm{l}$ of cell extracts diluted with Assay Buffer (1:4) for each sample. Each one of the analyte-specific antibodies was captured in beads with the same size $(5.4 \mu \mathrm{m})$ and different intensity in the red fluorescence channel (FL4). The analysis of the results was performed with a dedicated analysis Software (MultiBead Analysis Software, Enzolifescienses). The sensitivity of each analyte, based on the lower used standard, was the following: Akt (0.2 ng/mL), Hsp27 phospho - Ser82 (5.2 U/mL), Hsp27 phospho - Ser15 (3.4 U/mL), Hsp40 (0.2 ng/ $\mathrm{mL})$, Hsp60 (3.4 ng/mL), Hsp70 (0.2 ng/mL), Hsp90a (0.3 ng/ $\mathrm{mL})$, Akt phospho - Ser473 $(2.0 \mathrm{U} / \mathrm{ml})(8,34)$. For the analysis we used the FACS - Calibour flow cytometer equipped with 2 lasers (488nm, 635nm) and 6 parameters (Fsc, Ssc, FL1 - FL4).

\section{Statistical Analysis}

Correlation among total Akt, Akt phospho, HSP60, HSP70, HSP90a, HSP40, HSP27 phospho-ser82 and HSP27 phosphoser15 indices of tumor tissue were analyzed statistically using Spearman analysis. The differences in HSP expression between high-grade gliomas and meningiomas were estimated using two-tailed paired t-test. A 2 -sided $P$-value $<0.05$ was considered statistically significant.

\section{RESULTS}

Table I and II summarizes the patients' data. There was a significant positive correlation between HSP27 (pSer82) and HSP27 (pSer15) expression $(p=0.001)$. There was also a significant correlation between HSP90a and both total Akt and Akt (phospho) $(p<0.0001$ and $p=0.0057$ respectively). A significant positive correlation between HSP27 (pSer82), HSP27 (pSer15) and total Akt $(p=0.014$ and $p=0.02$ respectively) was also observed. HSP70 and HSP90 showed a strong parallel expression $(p<0.0001)$. When comparing highgrade gliomas with meningiomas, no significant difference was found for Akt (total) $(p=0.3), H S P 27$ (pSer82) $(p=0.9)$, HSP27 (pSer15) $(p=0.4)$, HSP60 $(p=0.9)$, HSP90a $(p=0.3)$ and Akt (phospho) $(p=0.17)$. We found significantly higher levels of HSP70 expression in meningiomas compared to gliomas $(p=0.04)$ and a trend towards higher levels of HSP40 expression in the meningiomas group compared to gliomas $(p=0.076)$. No significant correlation was found between Ki-67 index and HSP expression in gliomas or meningiomas.

\section{DISCUSSION}

The present study demonstrated substantial expression of HSP in brain tumors. We found expression of HSP27 (pSer82), HSP27 (pSer15), HSP40, HSP60, HSP70, HSP90a in both gliomas and meningiomas. Akt (total) and Akt (phospho) were also detected. Significantly higher levels of HSP70 and a trend towards higher levels of HSP40 were found in meningiomas compared to gliomas.

HSP expression is induced by stress such as irradiation, heat, anticancer agents and oxidating stress (11). Mammalian HSPs have been classified according to their size into six families: HSP100, HSP90, HSP70, HSP60, HSP40 and small HSPs (15 to $30 \mathrm{kDa}$ ) including HSP27 (17). HSP27 can form oligomers up to $1000 \mathrm{kDa}$. HSP27 is an ATP-independent chaperone that protects the cells from protein aggregation. HSP27 can be phosphorylated at three serine residues (Ser15, Ser78 and Ser82), and its dephosphorylation enhances oligomerization. HSP27 inhibits apoptosis by regulating upstream signaling pathways (27). Rane et al. showed that Akt phosphorylated HSP27 on Ser82 and this phosphorylation of HSP27 resulted in its dissociation from Akt. Additionally, the interaction between HSP27 and Akt was necessary for activation of Akt in intact neutrophils. Thus, HSP27 regulates apoptosis through control of Akt activity (25). Moreover, HSP27 facilitate the activation of the ubiquitin-proteasome pathway resulting in an increase in NF-kB activity that has an anti-apoptotic effect (24). HSP27 accumulation reduces the apoptotic process 
induced by alkylating agents in human colorectal cancer cells (13). Khalid et al. reported that HSP27 expression in gliomas correlated with histological grades of astrocytoma and with the Ki-67 index. However, HSP27 expression was only analyzed immunohistochemically (17). In our study we used the multiplex bead array assay, which allows quantification of multiple proteins simultaneously, in contrast to ELISA or
Western blot that require a similar amount of sample but where only one protein can be analyzed $(8,22,34)$. No significant correlation between $\mathrm{Ki}-67$ index and HSP expression in gliomas or meningiomas was found in the present study, possibly due to the limited number of cases. In another study, a comparative analysis of HSP27, alphaBC, HSP72, HSP73, and HSP90 expression in 24 paired samples of first resections

Table I: Patients' Data

\begin{tabular}{|c|c|c|c|c|c|c|c|c|c|c|}
\hline $\begin{array}{l}\text { Age/ } \\
\text { Sex }\end{array}$ & Diagnosis & Ki-67 & $\begin{array}{c}\text { AKT } \\
\text { (Total) } \\
\mathrm{ng} / \mathrm{ml}\end{array}$ & $\begin{array}{c}\text { Hsp27 } \\
\text { (pSer82) } \\
\text { u/ml }\end{array}$ & $\begin{array}{c}\text { Hsp27 } \\
\text { (pSer 15) } \\
\text { u/ml }\end{array}$ & $\begin{array}{l}\mathrm{Hsp40} \\
\mathrm{ng} / \mathrm{ml}\end{array}$ & $\begin{array}{l}\text { Hsp60 } \\
\mathrm{ng} / \mathrm{ml}\end{array}$ & $\begin{array}{l}\text { Hsp70 } \\
\mathrm{ng} / \mathrm{ml}\end{array}$ & $\begin{array}{l}\text { Hsp90 } \\
\text { alpha } \\
\text { ng/ml }\end{array}$ & $\begin{array}{c}\text { Akt } \\
\text { phospho } \\
\text { u/ml }\end{array}$ \\
\hline $55 / F$ & GBM & 5 & 0.88 & 14.95 & 6.62 & 1.85 & 5.23 & 2.88 & 0.86 & 2.19 \\
\hline $48 / F$ & GBM & 30 & 1.78 & 14.38 & 6.08 & 2.36 & 87.22 & 4.57 & 5.89 & 12.97 \\
\hline $68 / M$ & GBM & 30 & 0.78 & 1.74 & 4.92 & 1.1 & 1.1 & 1.77 & 1.17 & 0 \\
\hline $34 / M$ & $\mathrm{AOA}$ & 15 & 2.06 & 5 & 6.49 & 2.99 & 160.21 & 4.67 & 7.7 & 10.24 \\
\hline $59 / \mathrm{M}$ & GBM & 20 & 3.03 & 17.86 & 7.17 & 5.69 & 70.15 & 9.71 & 16.9 & 29.89 \\
\hline $57 / F$ & GBM & 60 & 1.69 & 54,96 & 9.1 & 2.94 & 108.4 & 7.3 & 1.58 & 12.97 \\
\hline $58 / M$ & GBM & 60 & 0.98 & 8.47 & 5.87 & 1.52 & 17.17 & 1.95 & 1.3 & 4.85 \\
\hline $54 / M$ & GBM & 35 & 0.71 & 8.47 & 5.93 & 1.16 & 0 & 1.23 & 1.18 & 0 \\
\hline $57 / M$ & GBM & 70 & 0.8 & 9.5 & 5.87 & 1.61 & 1.32 & 1.06 & 1.13 & 0 \\
\hline $62 / F$ & GBM & $\mathrm{n} / \mathrm{a}$ & 2.13 & 113.46 & 15.02 & 5.77 & 449.99 & 35.88 & 81 & 7.53 \\
\hline $50 / F$ & $\begin{array}{l}\text { Meningioma } \\
\text { Meningothelial }\end{array}$ & 0,5 & 3.09 & 17.86 & 6.3 & 9.14 & 421.55 & 158.4 & 63.43 & 27.01 \\
\hline $52 / \mathrm{M}$ & $\begin{array}{c}\text { Meningioma } \\
\text { Psammomatous }\end{array}$ & 4 & 6.25 & 33.05 & 7.68 & 20.49 & 134.69 & 118.03 & 44.14 & 155.51 \\
\hline $51 / F$ & $\begin{array}{l}\text { Meningioma } \\
\text { Meningothelial }\end{array}$ & 5 & 1.99 & 87.78 & 5.93 & 19.47 & 97.24 & 276.07 & 66.96 & 29.89 \\
\hline $51 / F$ & $\begin{array}{l}\text { Meningioma } \\
\text { Meningothelial }\end{array}$ & 1.5 & 0.89 & 9.5 & 6.3 & 1.88 & 1.75 & 1.77 & 1.43 & 15.73 \\
\hline $78 / F$ & $\begin{array}{c}\text { Meningioma } \\
\text { Atypical }\end{array}$ & 25 & 1.1 & 6.46 & 6.11 & 2.16 & 1.96 & 3.46 & 1.99 & 0 \\
\hline $50 / \mathrm{M}$ & Neurinoma & 1.29 & 1.29 & 6.46 & 5.36 & 1.7 & 17.17 & 4.06 & 2.5 & 12.97 \\
\hline $51 / M$ & $\begin{array}{l}\text { Meningioma } \\
\text { Meningothelial }\end{array}$ & 0,5 & 0.87 & 14.95 & 6.82 & 1.46 & 5.6 & 0.97 & 1.28 & 2.19 \\
\hline $48 / F$ & $\begin{array}{l}\text { Meningioma } \\
\text { Transitional }\end{array}$ & 0,5 & 0.86 & 13.26 & 6.39 & 1.29 & 5.73 & 2.32 & 1.67 & 0 \\
\hline $68 / M$ & Metastasis & $\mathrm{N} / \mathrm{A}$ & 1.56 & 12.16 & 6.49 & 3.01 & 139.65 & 8.72 & 15.98 & 0 \\
\hline
\end{tabular}

AOA: Anaplastic oligoastrocytoma, F: Female, GBM: Glioblastoma, M: Male, N/A: Non-available.

Table II: Average of Analytes Based on Different Diagnosis

\begin{tabular}{|c|c|c|c|c|c|c|c|c|}
\hline Diagnosis & $\begin{array}{c}\text { AKT } \\
\text { (Total) } \\
\text { ng/ml } \\
\text { Average }\end{array}$ & $\begin{array}{c}\text { Hsp27 } \\
\text { (pSer82) } \\
\text { u/ml } \\
\text { Average }\end{array}$ & $\begin{array}{c}\text { Hsp27 } \\
\text { (pSer15) } \\
\text { u/ml } \\
\text { Average }\end{array}$ & $\begin{array}{c}\text { Hsp40 } \\
\text { ng/ml } \\
\text { Average }\end{array}$ & $\begin{array}{c}\text { Hsp60 } \\
\text { ng/ml } \\
\text { Average }\end{array}$ & $\begin{array}{l}\text { Hsp70 } \\
\text { ng/ml } \\
\text { Average }\end{array}$ & $\begin{array}{l}\text { Hsp90 } \\
\text { alpha } \\
\text { ng/ml } \\
\text { Average }\end{array}$ & $\begin{array}{c}\text { Akt } \\
\text { phospho } \\
\text { u/ml } \\
\text { Average }\end{array}$ \\
\hline GBM & 1.42 & 27.09 & 7.40 & 2.67 & 82.29 & 7.37 & 12.33 & 7.82 \\
\hline Meningioma & 2.04 & 23.66 & 6.36 & 7.20 & 85.71 & 70.63 & 22.92 & 30.41 \\
\hline
\end{tabular}

GBM: Glioblastoma. 
and recurrences of glioblastomas revealed no impact of HSP expression on response to adjuvant radiochemotherapy and no modulation of HSP expression by radiochemotherapy (15). Recently, Shen et al. studied low-grade gliomas and reported that the HSP27 expression was downregulated compared to autologous para-cancerous brain tissues (29). We investigatedsite-specific phosphorylation of HSP27 at Ser82 and Ser15 in high-grade gliomas for the first time in the present study. There was a parallel high expression of HSP27 at Ser82 and Ser15 in these tumors. We also found a substantial expression of several HSPs in medulloblastoma with the more important HSP27 and HSP70 in a previous study (2). Regarding meningiomas, an immunohistochemical study revealed low HSP27 cytoplasmic immunoreactivity in 26 of 64 meningiomas (3). Using Western blotting, Yokoyama et al. detected HSP27 in every meningioma tissue homogenate of the cases studied (33). Similarly, we found substantial HSP27 expression at Ser82 and Ser15 in all meningioma cases. Thus, HSP27 is highly phosphorylated at both Ser82 and Ser15 in brain tumors.

HSP70 and HSP90 have been considered anti-apoptotic proteins similar to HSP27. Both HSP70 and HSP90 function as ATP-dependent molecular chaperones (30). In the present study, we found a strong linear correlation between HSP70 and HSP90a. HSP70 acts to suppress signals leading to Bax activation and thereby prevents the release of pro-apoptotic proteins from mitochondria (30). HSP70 and HSP90 can also suppress apoptosis by directly associating with Apaf- 1 and blocking the assembly of a functional apoptosome (4). Furthermore, JNK activation is believed to be an essential mediator of stress-induced apoptosis. Binding of HSP70 to JNK prevents its phosphorylation (20). HSP90 associates with a number of signaling proteins. Client proteins of HSP90 such as AKT, p53, MEK, STAT3, and Bcr-Abl are vital in tumor progression and HSP90 is required for the stability and function of these proteins (18). Hsp90 can bind to Akt in vivo and contributes to the functional stabilization of PI3K/ Akt signaling and cell survival. The blockade of the binding to HSP90 inactivates Akt and increases the sensitivity of the cells to apoptosis-inducing stimuli (26). Akt is activated by phospholipid binding and activation loop phosphorylation at Thr308 by PDK1 and by phosphorylation within the carboxy terminus at Ser473 (1). Hsp90 inhibition dramatically depleted intracellular PDK1, suggesting that loss of PDK1 may be the primary reason for Akt deactivation (31). In the present study we confirm the parallel expression of Hsp90a and both total Akt and (phospho) Akt. We chose to study HSP90a because only the induced HSP90a and not the constitutive HSP90 $\beta$ is upregulated in glioma (23). HSP90a has therapeutic implications since both Hsp90a gene silencing and the protein inhibitor approaches resulted in a dramatic reduction in cell viability (7).

The role of HSP60 in cancer has not been fully elucidated yet. Xanthoudakis et al reported that HSP60 has a pro-apoptotic role by facilitating the activation of pro-caspase- 3 by different upstream caspases, including caspase-6 (32). Cytosolic HSP60 prevents translocation of the pro-apoptotic protein Bax into mitochondria and thus promotes cell survival (28). Ghosh et al. reported that HSP60 is up-regulated in human cancers including some cases of glioblastoma and orchestrates a cytoprotective pathway that involves stabilization of survivin levels and restraint of $p 53$ function (12). To date, no other study has evaluated HSP60 expression in brain tumors. Herewith, we found expression of HSP60 in nearly all tumors studied, both in high-grade gliomas and meningiomas. Furthermore, we found expression of HSP40, also known as chaperone DnaJ, in all brain tumors. A trend towards higher expression in meningiomas was also detected. HSP40 has not been previously studied in brain tumors. HSP40 regulates HSP70 function. Both HSP90 and the HSP40/HSP70 system act to enhance the Akt pathway, which is important for cell survival $(9,26)$. The present study showed a parallel high expression of HSP40/HSP70/HSP90 in brain tumors.

In conclusion, our results demonstrated substantial HSP production in the tumor specimens examined, which we believe is the first time in which many different HSPs have been reported in brain tumors. Based on this finding and given that HSPs are an attractive strategy for anticancer therapy, further studies involving larger number of patients are obviously needed to clarify their relationship with tumor aggressiveness and prognosis.

\section{REFERENCES}

1. Alessi DR, Andjelkovic M, Caudwell B, et al: Mechanism of activation of protein kinase $B$ by insulin and IGF-1. EMBO J 15:6541-6565, 1996

2. Alexiou GA, Vartholomatos G, Stefanaki $K$, Patereli A, Dova L, Karamoutsios A, Lallas G, Sfakianos G, Moschovi M, Prodromou $\mathrm{N}$ : Expression of heat shock proteins in medulloblastoma. J Neurosurg Pediatr 12(5):452-457, 2013

3. Assimakopoulou M: Human meningiomas: Immunohistochemical localization of progesterone receptor and heat shock protein 27 and absence of estrogen receptor and PS2. Cancer Detect Prev 24:163-168, 2000

4. Beere HM, Wolf BB, Cain K, et al: Heat-shock protein 70 inhibits apoptosis by preventing recruitment of procaspase- 9 to the Apaf-1 apoptosome. Nat Cell Biol 2:469-475, 2000

5. Ciocca DR, Calderwood SK: Heat shock proteins in cancer: Diagnostic, prognostic, predictive, and treatment implications. Cell Stress Chaperones 10:86-103, 2005

6. Ciocca DR, Rozados VR, Cuello-Carrio'n FD, Gervasoni SI, Matar P, Scharovsky OG: Heat shock proteins 25 and 70 in rodent tumors treated with doxorubicin and lovastatin. Cell Stress Chaperones 8:26-36, 2003

7. Cruickshanks N, Shervington L, Patel R, Munje C, Thakkar D, Shervington A: Can hsp90alpha-targeted siRNA combined with TMZ be a future therapy for glioma? Cancer Invest 28:608-614, 2010

8. Elshal MF, McCoy JP: Multiplex bead array assays: Performance evaluation and comparison of sensitivity to ELISA. Methods $38: 317-323,2006$ 
9. GaoT, Newton AC: The turn motif is a phosphorylation switch that regulates the binding of $\mathrm{Hsp} 70$ to protein kinase C. J Biol Chem 277:31585-31592, 2002

10. Garrido C, Ottavi P, Fromentin A, et al: HSP27 as a mediator of confluence-dependent resistance to cell death induced by anticancer drugs. Cancer Res 57:2661-2667, 1997

11. Garrido C, Schmitt E, Candé C, Vahsen N, Parcellier A, Kroemer G: HSP27 and HSP70: Potentially oncogenic apoptosis inhibitors. Cell Cycle 2:579-584, 2003

12. Ghosh JC, Dohi T, Kang BH, Altieri DC: Hsp60 regulation of tumor cell apoptosis. J Biol Chem 283:5188-5194, 2008

13. Graner MW, Bigner DD: Chaperone proteins and brain tumors: Potential targets and possible therapeutics. Neuro Oncol 7:260 -278, 2005

14. Gyrd-Hansen M, Nylandsted J, Jäättelä M: Heat shock protein 70 promotes cancer cell viability by safeguarding lysosomal integrity. Cell Cycle 3:1484-1485, 2004

15. Hermisson M, Strik H, Rieger J, Dichgans J, Meyermann R, Weller M: Expression and functional activity of heat shock proteins in human glioblastoma multiforme. Neurology 54:1357-1365, 2000

16. Kato S, Kato M, Hirano A, Takikawa M, Ohama E: The immunohistochemical expression of stress-response protein (srp) 60 in human brain tumours: Relationship of srp 60 to the other five srps, proliferating cell nuclear antigen and p53 protein. Histol Histopathol 16:809-820, 2001

17. Khalil AA, Kabapy NF, Deraz SF, Smith C: Heat shock proteins in oncology: Diagnostic biomarkers or therapeutic targets? Biochim Biophys Acta 1816:89-104, 2011

18. Khong T, Spencer A: Targeting HSP 90 induces apoptosis and inhibits critical survival and proliferation pathways in multiple myeloma. Mol Cancer Ther 10:1909-1917, 2011

19. Mosser DD, Morimoto RI: Molecular chaperones and the stress of oncogenesis. Oncogene 23:2907-2918, 2004

20. Murshid A, Gong J, Stevenson MA, Calderwood SK: Heat shock proteins and cancer vaccines: Developments in the past decade and chaperoning in the decade to come. Expert Rev Vaccines 10:1553-1568, 2011

21. Nahleh Z, Tfayli A, Najm A, El Sayed A Nahl: Heat shock proteins in cancer: Targeting the 'chaperones'. Future Med Chem 4:927-935, 2012

22. Njemini R, Bautmans I, Lambert M, Demanet C, Mets T: Heat shock proteins and chemokine/cytokine secretion profile in ageing and inflammation. Mech Ageing Dev 128:450 - 454, 2007
23. Panner A, Murray JC, Berger MS, Pieper RO: Heat shock protein 90alpha recruits FLIPS to the death-inducing signaling complex and contributes to TRAIL resistance in human glioma. Cancer Res 67:9482-9489, 2007

24. Parcellier A, Schmitt E, Gurbuxani S, et al :HSP27 is a ubiquitinbinding protein involved in I-kappaBalpha proteasomal degradation. Mol Cell Biol 23:5790-5802, 2003

25. Rane M J, Pan Y, Singh S, et al: Heat shock protein 27 controls apoptosis by regulating Akt activation. J Biol Chem 278:27828-27835, 2003

26. Sato S, Fujita N, Tsuruo T: Modulation of Akt kinase activity by binding to Hsp90. Proc Natl Acad Sci U S A 97:10832-10837, 2000

27. Schmitt E, Gehrmann M, Brunet M, Multhoff G, Garrido C: Intracellular and extracellular functions of heat shock proteins: Repercussions in cancer therapy. J Leukoc Biol $81: 15-27,2007$

28. Shan YX, Liu TJ, Su HF, Samsamshariat A, Mestril R, Wang PH: $\mathrm{Hsp} 10$ and $\mathrm{Hsp} 60$ modulate $\mathrm{Bcl}-2$ family and mitochondria apoptosis signaling induced by doxorubicin in cardiac muscle cells. J Mol Cell Cardiol 35:1135-1143, 2003

29. Shen G, Liang S, Xu Z, et al: Downregulated expression of HSP27 in human low-grade glioma tissues discovered by a quantitative proteomic analysis. Proteome Sci 8:17, 2010

30. Stankiewicz AR, Lachapelle G, Foo CP, Radicioni SM, Mosser DD: Hsp70 inhibits heat-induced apoptosis upstream of mitochondria by preventing Bax translocation. J Biol Chem 280:38729-38739, 2005

31. Wei Q, Xia Y: Roles of 3-phosphoinositide-dependent kinase 1 in the regulation of endothelial nitric-oxide synthase phosphorylation and function by heat shock protein 90 . J Biol Chem 280:18081-18086, 2005

32. Xanthoudakis S, Roy S, Rasper D, et al: Hsp60 accelerates the maturation of pro-caspase-3 by upstream activator proteases during apoptosis. EMBO J 18:2049-2056, 1999

33. Yokoyama N, Iwaki T, Goldman JE, Tateishi J, Fukui M: Small heat-shock protein is expressed in meningiomas and in granulofilamentous inclusion bodies. Acta Neuropathol 85:248-255, 1993

34. Zhang R, Luo D, Miao R, et al: Hsp90 - Akt phosphorylates ASK1 and inhibits ASK1 - mediated apoptosis. Oncogene 24:3954 - 3963, 2005 